The European Food Safety Authority scientific opinion on a risk profile related to production and consumption of insects as food and feed

Finke, Mark D; Rojo, S; Roos, Nanna; van Huis, Arnold; Yen, A L

Published in:

Journal of Insects as Food and Feed

DOI:

10.3920/JIFF2015.x006

Publication date:

2015

Document version

Publisher's PDF, also known as Version of record

Document license:

CC BY

Citation for published version (APA):

Finke, M. D., Rojo, S., Roos, N., van Huis, A., \& Yen, A. L. (2015). The European Food Safety Authority scientific opinion on a risk profile related to production and consumption of insects as food and feed. Journal of Insects as Food and Feed, 1(4), 245-247. https://doi.org/10.3920/JIFF2015.x006 


\title{
The European Food Safety Authority scientific opinion on a risk profile related to production and consumption of insects as food and feed
}

\author{
M.D. Finke', S. Rojo ${ }^{2}$, N. Roos $^{3}$, A. van Huis ${ }^{4}$ and A.L. Yen ${ }^{5,6 *}$ \\ ${ }^{1}$ Mark Finke LLC, 17028 E Wildcat Dr, Rio Verde, AZ 85263, USA; ${ }^{2}$ Department of Environmental Sciences and Natural \\ Resources, University of Alicante, Apartado de Correos 99, 03080 Alicante, Spain; ${ }^{3}$ Department of Nutrition, Exercise \\ and Sports (NEXS), University of Copenhagen, Rolighedsvej 26, 1958 Frederiksberg, Denmark; ${ }^{4}$ Laboratory of Entomology, \\ Wageningen University, P.O. Box 16, 6700 AA Wageningen, the Netherlands; ${ }^{5}$ Biosciences Research Branch, Department \\ of Economic Development, Jobs, Transport E Resources, AgriBio, 5 Ring Road, La Trobe University, Bundoora, Victoria \\ 3083, Australia; ${ }^{6}$ School of Applied Systems Biology, La Trobe University, AgriBio, 5 Ring Road, Bundoora, Victoria 3083, \\ Australia; editor-in-chief@insectsasfoodandfeed.com
}

\section{Background: the need for an opinion}

The increased attention to the use of farmed insects as a novel protein source has raised the question of the safety of insects as human food and as animal feed. This was the background for the European Union (EU) Commission to mandate the European Food Safety Authority (EFSA) to conduct a review of the current knowledge about biological, chemical and environmental risks associated with production and consumption of insects. National authorities in some EU member states (Belgium, the Netherlands and France) have conducted national assessments (ANSES, 2015; FASFC, 2014; NVWA, 2014). However, in the EU, existing regulations constitute legal barriers for marketing insects for human consumption and as protein in animal feed for food producing animals.

For human consumption, foods not traditionally consumed in Europe need to be approved under the EU Novel Food regulation. Novel food is defined as food that has not been consumed to a significant degree by humans in the EU prior to 1997. However the regulation, formulated back in 1997, has left uncertainty about whether insects are covered or not and has therefore been interpreted differently in different member states. The Novel Food regulation is now in a final phase of revision and was approved by the EU parliament on October $28^{\text {th }}$ (http://tinyurl.com/ncblju5). The regulations will enter into force when finally approved by the EU council of ministers and will make it easier to get insects approved. In the revised regulations, insects are specifically mentioned to be viewed as novel foods and will need EU approval before they are put on the market. The procedure to get novel foods approved under the revised regulations is expected to accept that safe use in countries outside Europe can be referred to as an argument for getting the approval.
For the use of insects in animal feed, the EU has regulated which protein sources can be used for food producing animals. Protein from terrestrial animals is specifically prohibited in feed for food producing animals in the EU since the occurrence of prions in feed caused the BSE (bovine spongiform encephalopathy or mad cow disease) scandal in the 1980-1990s. This transmissible spongiform encephalopathies regulation consequently prohibits the use of insect protein, despite insects having no association with BSE.

\section{What the opinion addresses}

The EFSA opinion addresses the microbiological, chemical and environmental risks arising from the production and consumption of insects as food and feed. Hazards related to insects harvested from the wild were outside the terms of reference. Based on national assessments in the Netherlands and Belgium, 12 species of insects were initially identified, 
but after further information from European producers as well as outside Europe, the list of species identified to be farmed was nearly doubled in the opinion.

\section{What are the main conclusions?}

The EFSA opinion identifies the substrate used to feed the insects as the key entrance point for contaminations. For the purpose of assessing the risks, different potential substrates and the hazards in non-processed insects by substrate category relative to other animal protein sources were considered (Table 1).

With regard to biological hazards, pathogenic bacteria (such as Salmonella, Campylobacter and verotoxigenic Escherichia coli) may be present in non-processed insects depending on the substrate used and the rearing conditions. The prevalence of some pathogens, for example Campylobacter, may be lower compared to other nonprocessed animal protein sources since the pathogens do not appear to replicate in the intestinal tract of insects. It was found that insect pathogenic viruses occurring in farmed insects are specific for insects and not regarded as a hazard for vertebrate animals and humans. Viruses of vertebrates appear to survive in substrates and key issue here is the risk of transmission, which depends on the choice of substrate and processing.

It is concluded that mammalian prions cannot replicate in insects, and therefore insects are not considered to be possible biological vectors and amplifiers of prions. It is considered that insects may act as a mechanical vector of prions from ruminants or humans if farmed on a substrate or in an environment in which such infectious prions are present. In general, it is concluded that insects fed on substrates of non-human and non-ruminant origin should not pose any additional risk compared to the use of other food or feed. Insects fed on other substrates need to be evaluated.

The greatest influence on risk of accumulations of chemical contaminants such as heavy metals, mycotoxins, veterinary residuals or other chemical substances may be from the substrate, in relation to the insect species reared on it. Insects with a short life cycle and, thus limited repeated feeding, bioaccumulation is less likely to occur than in insects that are reared over a longer time period. From the very limited data available, it is seen that some species of insects may accumulate heavy metals, in particular cadmium, from their substrates. Several chemicals may accumulate, but data are lacking to conclude on the extent of accumulation in comparison with accumulation in food producing animals.

Another risk considered was allergens. This risk is associated with the insect species themselves. Allergic reaction and even anaphylactic shock in humans caused by consumption of insects have been documented. No information on allergy in pet and farm animals is reported in the literature. It is advisable that animals (pets or food-producing) fed on insect proteins are monitored for allergic reactions. Insect consumption by individuals allergic to house dust mites or crustaceans could trigger allergic reactions associated with cross reactivity. This can be mediated by proper labelling of the insect product.

Finally, the environmental risk of insect farming is expected to be comparable to other animal production systems. The adoption of existing waste management strategies should be applicable for managing waste from insect production. To evaluate this properly, environmental life cycle analyses of mass reared insect species will be required.

Table 1. Summary of the expected occurrence of hazards in non-processed insects compared to the occurrence in other protein sources of animal origin (condensed version based on Table 5 of the European Food Safety Authority report; EFSA, 2015).

\begin{tabular}{|c|c|c|c|}
\hline Substrate on which insects are reared & Biological hazards & Prions & Chemical hazards \\
\hline $\begin{array}{l}\text { Group A: feed materials authorized as feed for food producing } \\
\text { animals }\end{array}$ & Equal or lower & $\begin{array}{l}\text { Equal or lower, if does not include } \\
\text { material of ruminant origin }\end{array}$ & $\begin{array}{l}\text { Unknown if equal, } \\
\text { lower or higher }\end{array}$ \\
\hline $\begin{array}{l}\text { Group B: food produced for human consumption, but no longer } \\
\text { intended for human consumption (expired, etc.) }\end{array}$ & \multirow[t]{3}{*}{ Equal or lower } & \multirow{4}{*}{$\begin{array}{l}\text { - No expected occurrence, if } \\
\text { the substrate does not include } \\
\text { material of ruminant origin } \\
\text { - Unknown, if the substrate } \\
\text { includes material of ruminant } \\
\text { origin }\end{array}$} & \\
\hline $\begin{array}{l}\text { Group C: by-products from slaughterhouses (animals fit for human } \\
\text { consumption) }\end{array}$ & & & \\
\hline Group D: food waste from restaurants, catering and household & & & \\
\hline Group E: animal manure and intestinal content & Unknown & & \\
\hline Group F: other types of organic waste of vegetable nature & Equal or lower & No expected occurrence & \\
\hline Group G: human manure, and sewage sludge & Unknown & Unknown & \\
\hline
\end{tabular}


In summary, the opinion concluded that:

- the main risk are the food substrates and the handling and storage of farmed insects rather than the insects species themselves;

- mammalian prions cannot replicate in insects, and therefore insects are not considered to be possible biological vectors and amplifiers of prions unless ruminant or human substrates are used as feed;

- when currently allowed feed materials in the EU are used to feed insects, the possible occurrence of bacterial and viral hazards are equal or lower to other sources of protein of animal origin and should not pose any additional risk;

- chemical accumulation is the main unknown; heavy metals have been shown to accumulate in some species of insects but we have too little published data to draw further conclusions; and

- the use of other substrates currently not allowed in EU to feed insects, such as post-consumer food wastes and organic side stream manure, must be specifically evaluated.

\section{What is the significance of the opinion for the future use of insects as food and feed?}

The EFSA opinion acknowledged the constraints in formulating the report: restriction to a relatively small number of farmed insect species, the lack of detailed information about the magnitude and frequency of the use of insects as food and feed in Europe, and limited studies on bacteria, viruses, parasites and prions associated with food and feed insects, chemical contamination, allergens, processing, and the potential environmental impact of insect farms.
It is a complex document and there will be some aspects that not everyone will agree with. Most importantly it is a definite statement that risks of using insects as food or feed are no greater than those associated with other animals. However it does open the door for a more detailed discussion on framing the important food safety and security questions and directions for future research and industry development associated with using farmed insects as food or as feed. Despite its limitations, this scientific opinion is a valuable resource for the EU Commission to ensure that the use of insects as food and feed is approached in a uniform fashion within the EU and beyond.

\section{References}

European Food Safety Authority Scientific Committee (EFSA), 2015. Scientific opinion on a risk profile related to production and consumption of insects as food and feed. EFSA Journal 13: 4257.

Federal Agency for the Safety of the Food Chain (FASFC), 2014. Food safety aspects of insects intended for human consumption. Common advice of the Belgian Scientific Committee of the Federal Agency for the Safety of the Food Chain (FASFC) and of the Superior Health Council (SHC). FASFC, Brussels, Belgium. Available at: http:// tinyurl.com/kwvpb7o.

French Agency for Food, Environmental and Occupational Health and Safety (ANSES), 2015. Opinion on the use of insects as food and feed and the review of scientific knowledge on the health risks related to the consumption of insects. ANSES, Maisons-Alfort, France. Available at: http://tinyurl.com/oru9ly9.

Netherlands Food and Consumer Product Safety Authority (NVWA), 2014. Advisory report on the risks associated with the consumption of mass-reared insects. NVWA, Utrecht, the Netherlands. Available at: http://tinyurl.com/pb3w7et. 
